\title{
乾燥土に対する平板の運動摩擦特性について*
}

畠昭 治 郎** 室達 朗***

\section{The Characteristics of the Moving Friction between a Plate and Dry Soil}

\author{
by
}

\section{Shōjiro Hata and Tatsuro Muro}

(Faculty of Engineering, Kyoto University, Kyoto)

\begin{abstract}
In this paper the characteristics of the moving friction of a plate on dry soil are investigated; the differences of the moving friction of steel and rubber plates on sandy soil mixed with gravel, and on silty soil respectively, are found out in several confining conditions of the soil particles, and the antifrictional effects with a vibrating plate are exemplified.

When a plate is tracted on dry soil, the void ratio of the soil under the plate approaches the critical void ratio, independently of the initial degree of compaction. In this case the confining soil particles drop to the minimum of degree. But when the soil particles are confined in a sample box used in this friction test, the confining soil particles increase in degree generally with decrease in the thickness of soil samples, and when they are confined in the densest state, the rotation of soil particles are inhibited, and the moving frictional resistance does not decrease by the rolling friction. In this case, the confining soil particles reach their maximum degree. When a vibrated plate is tracted on dry soil, the rolling friction of soil samples decreases remarkably by the kinetic energy given by the plate to each soil particle, even if the void ratio is constant. In this case, the moving frictional resistance decreases, and especially there is considerable decrease of optimum frequency.

For these phenomena it is assumed that the degree of confining of the soil particles is represented by the void ratio, and that the coefficient of the mutual rolling friction between the soil particles is proportional to the number of contact points with the adjacent soil particles and so is variable with the kinetic energy of the vibrated soil particles. It may therefore be theoretically concluded that the coefficient of the moving friction is expressed by the function of the void ratio. (Received July 3, 1967)
\end{abstract}

\section{1 まえがき}

土工材料の掘削・積み込み・運搬などの作業におい $\tau$, 機椷作業部分と土との間の相対運動に伴って発生 する運動摩擦は，材料間相互の複雑な諸条件に支配さ れるために，理論的にその機構を解明するととは非常 に困難である。しかし，実際の土工作業において，よ り合理的かつ耐久性のある土工機械作業部分の設計・ 製作が要求される以上，われわれは，種々の条件に対 する運動摩擦特性を把握する必要がある。乙てでは, まず乾燥土に対する平板の運動摩擦特性について, 試 料土を充てんした土槽上で平板をけん引した場合, お よび摩擦箱の中に試料土を拘束した場合の拘束度と摩 擦抵抗の関係を求めるととと, 平板にけん引方向の振 動を与えた場合の振動による摩擦抵抗の低減という 2 点を主眼として研究を行なったものである。試料土は れき交り砂およびシルト質土であり, 土工作業で最も

* 原稿受理 昭和 42 年 7 月 3 日

** 京都大学工学部 京都市左京区吉田本町

**** 正 会 員 京都大学工学部 京都市左京区吉田本町
広く用いられる鉄板およびゴム板について，土の締固 め度, 拘束度および平板のけん引速度, 振動数などの 運動摩擦抵抗に及ぼす諸特性に関する実験的考察を行 なった結果について述べる。

\section{2 実験方法ならびに実験装置}

本実験に用いた試料土はれき交り砂およびシルト質 土であり，その土性および粒径加積曲線は, Table I および Fig. 1 亿示すとおりである。にれぞれの試料土 は, 乾燥状態において幅 $70 \mathrm{~cm}$, 長さ $250 \mathrm{~cm}$, 深さ 25 $\mathrm{cm}$ の木製土槽に充てんし，自重 $120 \mathrm{~kg}$ の円筒ローラ で転圧し，その表面を平滑に成形したものである。 そ

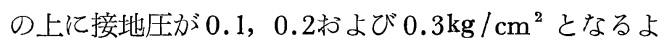
うに，直接重錘を載荷した鉄板あるいはゴム板をおき， ワイヤロープによってそれをけん引するときの土と平 板との間の運動摩擦抵抗を測定した. Fig. 2 の実験装 置概略図に示すように, 動力は 2 馬力モー夕を用い, 1/50亿減速した巻取りドラムによってワイヤロープを けん引し，摩擦抵抗力は，ドラムの直前に設けたけん 引力測定用トルクメータ (100kgm 用) を用い，増幅 
Table I. Soil properties of sample.

\begin{tabular}{|c|c|c|c|c|c|c|c|}
\hline & \multirow{3}{*}{$\begin{array}{l}\text { Maximum } \\
\text { grain size } \\
\quad(\mathrm{mm})\end{array}$} & \multirow{3}{*}{$\begin{array}{l}\text { Talbot's } \\
\text { exponent }\end{array}$} & \multirow{3}{*}{$\begin{array}{l}\text { Specific } \\
\text { gravity }\end{array}$} & \multirow{3}{*}{$\begin{array}{l}\text { Water } \\
\text { content } \\
(\%)\end{array}$} & \multirow{2}{*}{\multicolumn{3}{|c|}{$\begin{array}{c}\text { Dry density after compaction } \\
\qquad\left(\mathrm{g} / \mathrm{cm}^{3}\right)\end{array}$}} \\
\hline & & & & & & & \\
\hline & & & & & 2 & 6 & 40 \\
\hline $\begin{array}{l}\text { Sandy soll } \\
\text { mixed with } \\
\text { gravel }\end{array}$ & 4.80 & 0.87 & 2.65 & 3.0 & 1.45 & 1.62 & 1.84 \\
\hline Silty soll & 1.50 & 0.87 & 2.73 & 3.4 & 1.36 & 1.49 & 1.60 \\
\hline
\end{tabular}

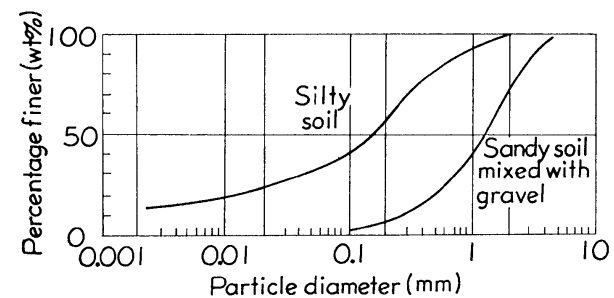

Fig. 1. Grain-size distribution curves.

器を通して記録計に自記させるものである。またけけ ん引速度は動力系統のVベルト車の大きさを交換し， 巻取りドラムの回転数を調節するてとによって変速で きる．鉄板およびゴム板は， $50 \mathrm{~cm} \times 20 \mathrm{~cm} \times 0.9 \mathrm{~cm}$ の く形板であり，鉄板は普通炭素銅を鉔造加工したまま で表面仕上を行なっていないもの，またゴム材は普通 の加硫天然ゴムを使用した，鉄板の組成，強度および 表面あらさなどについては Table II に示してある. これらの平板を木製土槽上でけん引する場合，まずロ

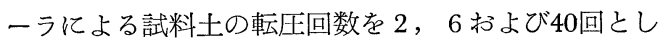
た場合の締固め度と運動摩擦抵抗との関係を求め, そ

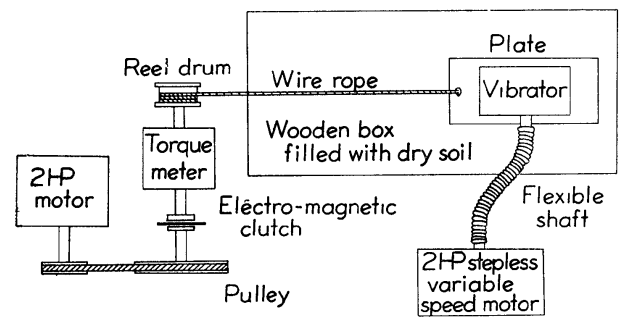

Fig. 2. Apparatus for friction test.

Table II. Physical properties of steel plate.

\begin{tabular}{c|c|c|c|c|c}
\hline $\begin{array}{c}\text { Chemical } \\
\text { composition } \\
(\%)\end{array}$ & $\mathrm{C}$ & $\mathrm{S} 1$ & $\mathrm{Mn}$ & $\mathrm{S}$ & $\mathrm{P}$ \\
\cline { 2 - 5 } & $0.30 \sim 040$ & $<0.30$ & $060 \sim 0.80$ & $<0.06$ & $<0.06$ \\
\hline $\begin{array}{c}\text { Tensile } \\
\text { strength } \\
\left.\mathrm{kg} / \mathrm{mm}^{2}\right)\end{array}$ & $41 \sim 50$ \\
\hline $\begin{array}{c}\text { Roughness } \\
\text { of surface }\end{array}$ & 6-S and 50-S \\
\hline
\end{tabular}

の後締固め度を一定にした場合の平板のけん引速度を $3.3 ， 6.8 ， 9.8$ および $13.0 \mathrm{~cm} / \mathrm{sec}$ お 4 段に変速して 平板の運動速度に対する摩擦抵抗の変化について実測 し，平板と土との間の材質による相違について比較検 討を行なった.

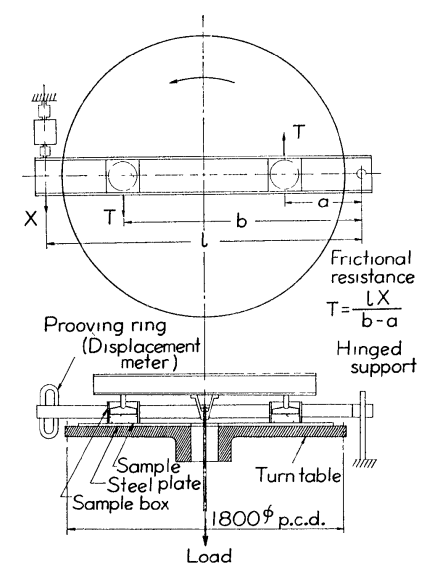

Fig. 3. Rotary type testing machine for friction test.

一方，試料土を摩擦箱の中に拘束した場合の拘束の 程度が，運動摩擦抵抗に及ぼす影響について試験する ために, Fig. 3 に示す試験装置を試作した。 てれは直 径 $1800 \mathrm{~mm}$, 厚さ $50 \mathrm{~mm}$ の鋼製回転板上に鉄板を載せ, その上に 2 個の直径 $150 \mathrm{~mm}$ の円筒摩擦箱を同一円周 上に設置し，その中に試料土を充てんし，直接レバを 通して載荷するものである。摩擦箱取付けわくは, 一 端をヒンジで固定し, 他端を $1 \mathrm{t}$ 用引張計に連結して, 鋼製回転板を回転させた場合の 2 個の摩擦抵抗力の反 力を, 引張計に取り付けた差動変圧機を通して, 直接 オシログラフに自記させる構造とした，ててでは, 特 そ鉄板の表面あらさおよび摩擦速度の影響について試 験するとともに，試料土の層厚によって拘束の程度を 変えた場合の運動摩擦抵抗に関する測定を行なった。

さらに, 平板のけん引方向に振動荷重を与えた場合 の運動摩擦抵抗の低減について試験するために, 前述 の木製土槽を使用し, 振動発生装置として自重 $42 \mathrm{~kg}$, 
最大起振力 $500 \mathrm{~kg} の$ two-mass 型起振機を用いた. 起 振機は, 平板上に載荷重とともに設置し, 動力は 2 馬 力のモータから無段変速機を通し，フレキシブル・シ ャフトによって伝達するものである. 振動数は無段変 速機によって $10 \mathrm{cps}$ から最大 $40 \mathrm{cps}$ まで変化させ, 振動による減摩効果について振動を与えない場合と比 較検討を行なった。

\section{3 実 験 結 果}

試料土を乾燥状態において木製土槽内に充てんし， その上で平板に振動を与えないでそのままけん引する 場合の運動摩擦抵抗と移動量との関係は, その一例を, Fig. 4 亿示すように接地圧が増大するとともに鉄板と ゴム板とでは異なった挙動を示している．特に鉄板と れき交り砂との摩擦においては，けん引当初慣性によ る 5 サイクル程度の振動が伴うのである。乙れはでく 低いけん引速度に対してはみられない現象であり，速 度が高くなるほど顕著に現われるもので，初期の急速 な加速に対する実験装置全体の影響によるものと考え られる。したがって，運動摩擦抵抗については，け ん引初期における過渡的振動か減衰して定常状態に達 するまで平板をけん引し，そのときに発生するわずか な振動はてれを平均化して整理し，また摩擦箱による 摩擦試験においては，二つの摩擦反力の合力として測 定するために，本文ではこれらの平均值をもって測定

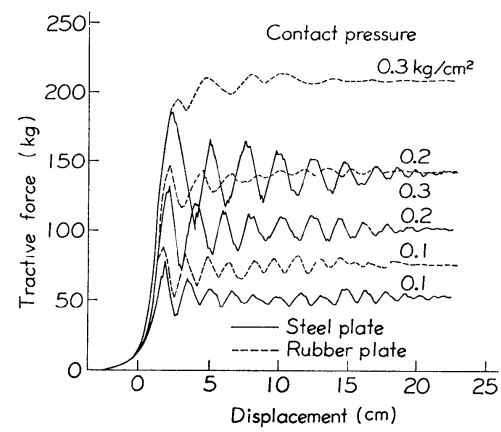

Fig. 4. Relationship between tractive force and displacement of plate.
值とする。

摩擦速度による運動摩擦抵抗の変化について, Fig. 5 亿示したのは，乾燥シルト質土についてけん引速度 を $3.3 \mathrm{~cm} / \mathrm{sec}$ から $13.0 \mathrm{~cm} / \mathrm{sec}$ まで変化させた場合の けん引抵抗力と接地圧との関係であり，また Fig. 6 に 示したのは，摩擦箱による摩擦試験において，摩擦速 度を $10.4 \mathrm{~cm} / \mathrm{sec}$ から $31.7 \mathrm{~cm} / \mathrm{sec}$ の高速度にした場 合の鉄板とれき交り砂との間の運動摩擦抵抗の変化で ある。一般に，けん引速度による影響は顕著には現わ れないが，けん引速度の増大とともにわずかに運動摩 擦抵抗は低下する傾向がみられる。

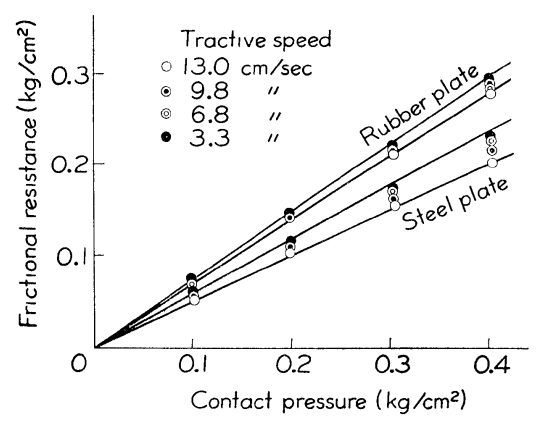

Fig. 5. Frictional resistance between plate and silty soil.

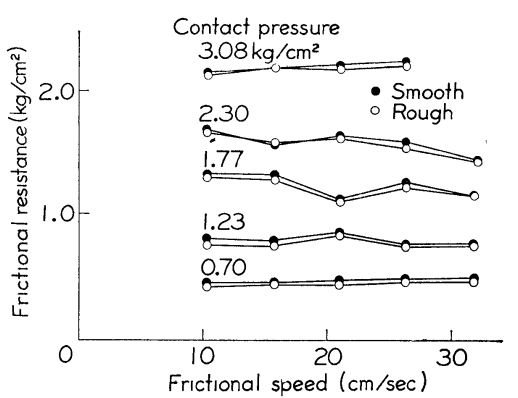

Fig. 6. Relationship between frictional resistance, frictional speed and roughness of surface.

Table III. Coefficient of moving friction between plate and dry soil.

\begin{tabular}{|c|c|c|c|c|c|c|}
\hline \multirow{3}{*}{ Sample } & \multirow{3}{*}{$\begin{array}{l}\text { Material } \\
\text { of plate }\end{array}$} & \multicolumn{2}{|c|}{ Test with traction of loaded plate } & \multicolumn{3}{|c|}{ Test with friction box } \\
\hline & & \multirow{2}{*}{$\begin{array}{c}\text { Speed of traction } \\
\text { is constant }(=33 \mathrm{~cm} / \mathrm{sec}) \\
\text { Number of roller pass } \\
2 \sim 40\end{array}$} & \multirow{2}{*}{$\begin{array}{l}\text { Number of roller } \\
\text { pass is constant }(=6) . \\
\text { Speed of traction } \\
3.3 \sim 13.0(\mathrm{~cm} / \mathrm{sec})\end{array}$} & \multirow{2}{*}{$\begin{array}{c}\text { Thickness of sample } \\
\text { is constant }(=5 \mathrm{~mm}) \text {. } \\
\text { Friction spced } \\
7.7 \sim 25.2(\mathrm{~cm} / \mathrm{sec})\end{array}$} & \multicolumn{2}{|c|}{$\begin{array}{l}\text { Friction speed is } \\
\text { constant }(=10 \mathrm{~cm} / \mathrm{sec}) \text {. } \\
\text { Thickness of sample }\end{array}$} \\
\hline & & & & & $20 \mathrm{~mm}$ & $3 \mathrm{~mm}$ \\
\hline \multirow{2}{*}{$\begin{array}{l}\text { Sandy soil } \\
\text { mixed with } \\
\text { gravel }\end{array}$} & Steel & $0.47 \sim 0.52$ & $0.48 \sim 0.50$ & $0.63 \sim 0.73$ & 0.58 & 078 \\
\hline & Rubber & $0.61 \sim 0.64$ & $0.59 \sim 0.65$ & - & - & - \\
\hline \multirow{2}{*}{ Silty soll } & Steel & $0.53 \sim 056$ & $0.48 \sim 0.56$ & - & 071 & 0.98 \\
\hline & Rubber & $0.69 \sim 0.73$ & $0.68 \sim 0.72$ & 一 & - & - \\
\hline
\end{tabular}


鉄板の表面あらさによる影響については Fig. 7 亿示 すように，表面のなめらかであるほうが，運動摩擦抵 抗はわずかに増加する傾向がみられた。

また, 摩擦箱の中に試料土を拘束し, 試料の層厚に

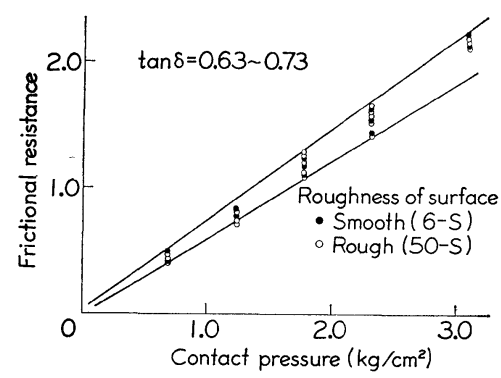

Fig. 7. Coefficient of moving friction between steel plate and sandy soil mixed with gravel.

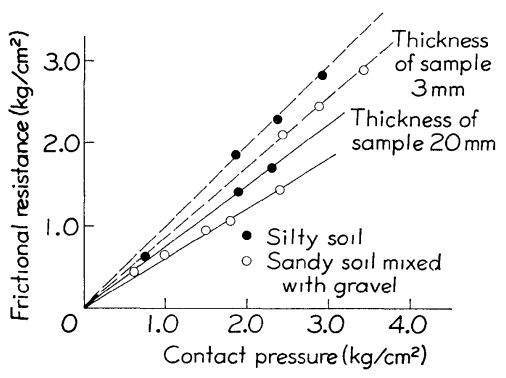

Fig. 8. Difference of frictional resistance due to thickness of soil sample.
よる運動摩擦抵抗の変化については，Fig. 8 に示すよ うに，粒径の細かいシルト質土のほうが，れき交り砂 に比べてかなり大きな運動摩擦係数を与えるが，いず れも, 試料土の首厚によって土粒子自身の移動の難易 が異なり，試料土の層厚を薄くするほど土粒子の移動 が拘束されるために，著しく運動摩擦係数は增加して いる．乙のように個々の土粒子の移動を拘束する場合 に対して，土槽上で平板をけん引する場合には，平板 直下における土粒子の粒子間の間げきは, 初期の締固 め程度にかかわらず，ある程度けん引儿た後において は，限界間げき比まで増加すると考光られるので，そ の運動摩擦抵抗もかなり減少すると考元てよい，以上， 無振動時における運動摩擦係数の実測值を, 各場合に ついてまとめると Table III のようになる。

次に，土槽内において，円筒ローラによる転圧回数 を6 回として締め固めた乾燥れき交り砂および乾燥シ ルト質土について，平板にけん引方向の振動を与光て， 土槽上で平板をけん引した場合の運動摩擦係数が，土 に与学られる振動加速度に対して, ぞの程度低下する かについて実験を行なった．Fig. 9 亿示すように，横 軸に振動加速度, 縦軸に無振動時の摩擦係数 $\tan \delta_{0}$ に 対する振動時の摩擦係数 $\tan \delta$ の比をとると, 振動に よる土の流動化現象のために平板のけん引抵抗は減少 し，振動加速度が $3000 \mathrm{gal}$ (振動数は約 $30 \mathrm{cps}$ ) にな ると，著しく低下してくる，ての図にみるように，特 にけん引速度が小さいほどその傾向は著しいととがわ かる、乙れは，振動の土に与える影響圈
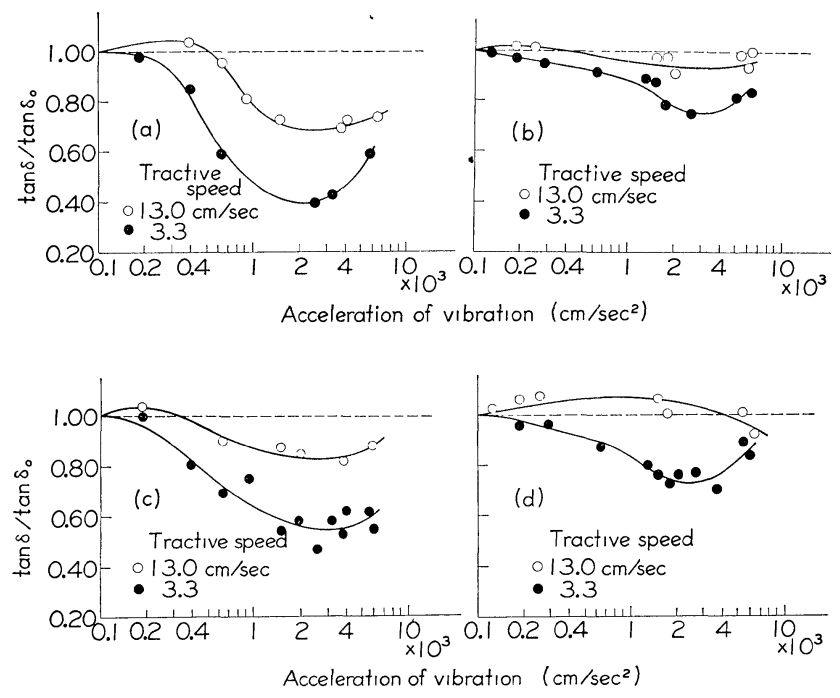

(a) Steel plate and sandy soil mixed with gravel.

(b) Rubber plate and sandy soil mixed with gravel.

(c) Steel plate and silty soil.

(d) Rubber plate and silty soil.

Fig. 9. Relationship between acceleration of vibration and ratio of coefficient of friction vibrated to nonyibratẹ,
が速度が大きくなると発達しにくいと考 えられる、また，鉄板とゴム板とを比較 した場合に，鉄板のほうが振動効果をよ く土に伝ぱするために，摩擦抵抗に著し い低下がみられる。それに対して，ゴム 板のほうでは, 同じ振動加速度を与えた 場合にもかなりの振動エネルギを吸收す るために，その影響はそれほど顕著には みられなかった。

\section{4 考察 \\ 4.1 土の拘束度と運動摩擦係数との 関係}

乾燥土に対する平板の運動摩 擦係数 は, 平板の材料によって当然異なるが， 同じ材料に対しても土に与える拘束条件 によってかなり変動する。乙れは，一般 に個々の土粒子が外力を受けて移動する 場合に，粒子の大きさ・形状による他の 土粒子相互間のかみ 合せの程度によっ て, 土粒子の回転または並進移動に対す 
る抵抗力か湾化するためである．また，平板と土粒子 間の摩擦抵抗は，主として土粒子の稯角部によるひっ かき作用によるものであり，間げき比か増大して粒子 がてろがる場合には，著しく摩擦抵抗は減少する。た とえば，鉄板の表面あらさがなめらかであるより，粗 な場合のほうが粒子のころがり現象をひき起てさせる ために，また摩擦速度が増大する場合および平板を振 動させるとき，てろがり現象が多く発生するために運 動摩擦抵抗は減少したと考光られる。

一般に，土粒子相互のかみ合せ，すなわち土の拘束 度は粒子の間げき比によって表現されると仮定すると， 間げき比の減少とともに運動摩擦係数か増大するとと は，前述の実駼例からも明らかである。いま，ての関 係を理論的に説明するために，最も簡単なモデルとし て土粒子を球に仮想し，均一な粒径を有する球の集合 体について，単一球体伤用する力の平衡式から間げ き比の摩擦係数に及ぼす影響について解析する。

G.W. Thurston と H. Deresiewicz は, 面心立方 体構造に配列した互いに隣接する球の集合体について, 破壊面を仮想し，球が最も密に配列した六角形構造を もつ球体首が，隣接する球体層を乗りてえて変形する のに必要な力 $D$ は，次式で算定できるととを導いた。

$$
\frac{D}{2 R^{2} \sigma_{0}}=\frac{3+4 \sqrt{6} f}{2(\sqrt{6}-f) \cos \beta-(\sqrt{3}+4 \sqrt{2} f) \cos \gamma}
$$

とてに， $D$ の作用方向は層の方向と $\beta$ の角度をな し，層の法線方向と $\gamma$ の角度をなしている， $R$ は球 の半径, $f$ は球体相互間の摩擦係数であり, $\sigma_{0}$ は初 期の等方圧力である。乙の球体首に作用する垂直力と せん断力の比をとり，てれを $\tan \phi$ とおくと次式力導 かれる。

$$
\tan \phi=\frac{D \cos \beta}{2 \sqrt{3} R^{2} \sigma_{0}+D \cos \gamma}=\frac{\sqrt{3}+4 \sqrt{2} f}{2(\sqrt{6}-f)}
$$

上式において，1個の土粒子が隣接する他の 2 個の 土粒子の谷線に沿って移動するに必要な合力の傾斜角 は, 摩擦係数 $f$ にって一義的に決定される。しか し，土粒子間の摩擦係数 $f$ は，土粒子の材質のみなら ず土粒子の形状および角張りなどによっても異なる。 こてでは，乙れらの諸条件は一定であるとして土粒子 が外力を受けて移動する場合に，土粒子が最も密な状 態にあるときには粒子の回転は許されないが，間げき 比の増加とともに粒子は回転しやすくなる。乙の粒子 の回転によって粒子間の摩擦の一部分は，てろがり摩 擦に転換するが，間げき比の増減に伴ってどの程度摩 擦係数が低下するかについて，次の仮説をたてると都 合がよい。

“1 個の土粒子が隣接する他の土粒子 1 個から外力 を受けた場合，その外力にどの程度抵抗するか，すな
わち 2 個の土粒子間のかみ合せ程度は，その粒子に接 点を有する隣接粒子の数に比例する”.

すなわち，乙の場合 2 個の土粒子間化作用する粒子 間力に対して，土粒子が移動するときの摩擦力を算定 するための摩擦係数を，1個の土粒子に隣接する平均 接点数を計算するととにより，間げき比の関数として 表わすてとができる.

いま，均一な粒径を有する球が最も密に配列された 六角形構造を単位とする球体層について考える。粒子 の全個数を $N$ ，粒子 1 個の投影面積を 1 とし，粒子 の配列されている全面積を $A$ とすると粒子 1 個あた りの接点の数 $f_{0}$ は 6 であり, この場合の間げき比 $e_{0}$ は， $(A-N) / N$ で与光られる。 さて，ての中から $n$ 個 の粒子を取り去った後の粒子 1 個あたりの平均接点数 を $f_{n}$ とし，間げき比を $e_{n}$ とすると次式が成立する.

$$
\begin{gathered}
f_{n}=\frac{6 N-12 n}{N-n}=6-\frac{6 n}{N-n} \\
e_{n}=\frac{A-(N-n)}{N-n}
\end{gathered}
$$

(3)抢よび(4)式から， $n$ を消去すると

$$
f_{n}=6\left(2-\frac{N}{A}\right)-\frac{6 N}{A} e_{n}
$$

となり,一般に, 粒子の接点数は間げき比の増加に対 して直線的減少するととがわかる。

したがって，間げき比 $e_{n}$ 亿対する粒子間の摩擦係 数 $f$ は，(5)式で与えられる接点数代比例するとして, 次式で表わすてとができる。

$$
\begin{aligned}
f & =k f_{n} \\
& =6 k\left(2-\frac{N}{A}\right)-\frac{6 k N}{A} e_{n} \\
& =a-b e_{n}
\end{aligned}
$$

ことに， $a$ および $b$ は正の定数である。乙れを(2)式 に代入して

$$
\begin{aligned}
\tan \phi & =\frac{\sqrt{3}+4 \sqrt{2}\left(a-b e_{n}\right)}{2\left\{\sqrt{6}-\left(a-b e_{n}\right)\right\}} \\
& =\frac{k_{1}-k_{2} e_{n}}{k_{3}+k_{4} e_{n}}
\end{aligned}
$$

乙てに， $k_{1}, k_{2}, k_{3}$ および $k_{4}$ は，いずれも正の定数 であるから(7)式を $e_{n}$ 亿関して微分すると

$$
\frac{d \tan \phi}{d e_{n}}=-\frac{k_{2} k_{3}+k_{1} k_{4}}{\left(k_{3}+k_{4} e_{n}\right)^{2}}<0
$$

となり, $\tan \phi$ は $e_{n}$ の増加とともに減少する関数で あるととが証明された。

Fig. 10 に示したように, $\tan \phi$ は最も密な状態 $e=$ $e_{0}$ から $e$ の増加とともに減少し，土槽上で平板をけ ん引していく場合に充分変位した後においては, 限界 間げき比 $e=e_{c}$ 亿まで低下するのである。一方, 摩擦 箱の中に土粒子を拘束した場合には，乙れらの中間の 值をとると考えられる。 


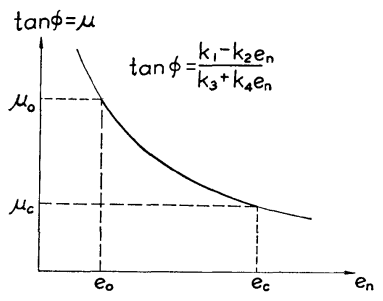

Fig. 10. Relationship between $\tan \phi$ and void ratio $e_{n}$.

以上は，鉄板またはゴム板とその直下の土粒子が完 全に密着していると仮定して解いたものであるが，実 際には，平板の材質によって土䊑子との間に滑動を生 じ，そのために土粒子相互のせん断抵抗力が充分に発 揮されず，(7)式で与えられる $\tan \phi$ に比べて実際の運 動摩擦係数は小さくなる.

\section{$\mathbf{4 \cdot 2}$ 振動による減摩効果について}

平板に振動を与えてけん引する場合，振動体と振動 圈内にある土塊との固有振動数は，Fig.11に示すよう
著しく減少する，前述の(6)，(7)式において，実際上間 げき比が無振動時と変わらないとしても，乙ろがり摩 擦 $f$ が減少するために(6)式で示した $e_{n}$ は増加する. 特に固有振動数において $e_{n}$ は最も增加するので，(7) 式で与兄られる $\tan \phi$ は最小值をとると考光られる。

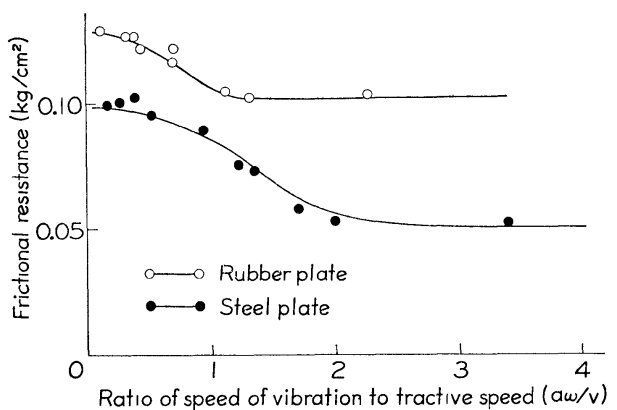

Fig. 12. Relationship between frictional resistance and ratio of speed of vibration to tractive speed, for sandy soil mixed with gravel and contact pressure $0.2 \mathrm{~kg} / \mathrm{cm}^{2}$.

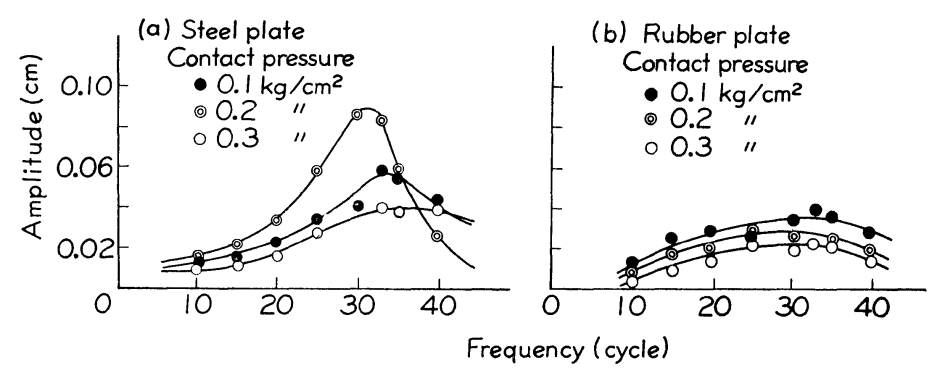

Fig. 11. Relationship between amplitude and frequency.
次に，振幅と角速度の積で表わ される平板の振動速度とけん引速 度について，てれらの両者の比と けん引抵抗力との関係をプロット すると，Fig. 12のようになる。そ の結果, 摩擦抵抗は鉄板について は $a \omega / v \doteqdot 2.0$ で,また,ゴム板に ついては $a \omega / v \fallingdotseq 1.0$ 亿至るまで徐 々に減少した後一定值となる傾向 がある。乙のように，振動速度が
に，平板の材質にかかわらず板の振幅が最高值を示す $30 \mathrm{cps}$ の近傍に存在する. したがって, 運動摩擦係数 は, この固有振動数において振動体と土とが最も共振 し，土粒子間の摩擦抵抗力の減少によってかなり大き な流動化現象を呈するために，最も低下する。

また, 振動加速度についても同様に, 運動摩擦抵抗 は, Fig. 9 に示したように，最初わずかに増加するの もあるがしだいに減少し，2000〜3000 gal で最低值 を示す. それ以上の振動加速度に対して逆に増加して いく傾向は, 前述の固有振動数による現象と同じであ る.

したがって，振動数または振動加速度が小さい場合 には, 土粒子の骨格構造が破壇され, 振動を与えない 場合に比べて間げき比は減少する。そのために，運動 摩擦係数は無振動時にわけるよりもわずかに増加する のである、しかし，振動数が増加するとともに振動加 速度も増大し, 個々の土粒子に非常に大きな運動エネ ルギを与えるために土粒子相互のてろがり摩擦 $f$ が
平板のけん引速度よりもある程度以上になれば，減摩 効果を最も発揮するてとができるのである.

\section{5 あとがき}

土槽上で平板をけん引する場合には，平板の材質に よって平板と土粒子との間の滑動による影響は異なる が，土粒子の間げきは当初の締固め度に関係なく限界 間げき比に近づくために，拘束度は最も低下するので， いずれの場合にも運動摩擦係数は最小となる。しかし， 摩擦箱の中に土粒子を拘束し，特に試料土の層厚を薄 くしていくほど，土粒子はてろがりがたくなり，土粒 子が最も密に拘束された場合には，粒子の回転は許さ れないので平板との間の運動摩擦抵抗は最大となる。 摩擦速度の増加によって, また鉄板の表面あらさが粗 になるほど，摩擦係数がわずかに減少するという事実 も土粒子間のてろがり摩擦によって説明される。

次に, 平板にけん引方向の振動を与光た場合, 運動 摩擦係数は振動数, 30cps, 振動加速度 2000～3000gal で著しく低下し，ての共振点をすぎるとふたたび増加 
する傾向がみられた。 また，けん引速度は小さいほど 減摩効果を高めることができる。乙れらの現象は，土 粒子に与えられる運動エネルギによって，土粒子聞の ころがり摩擦がどの程度減少するかによって説明する ことができる.ゴム板と鉄板とを比較した場合，与え られる振動エネルギが同じであっても, ゴム板は, 振 動エネルギをかなり吸収するために, 土塊に与える振 動エネルギは小さい，そのために，振動時の摩擦抵抗 は鉄板に比べてあまり減少しない。

理論的にてれらの現象を説明するために，土粒子の 拘束度を間げき比によって表現し，土粒子相互のてろ
がり摩擦係数が隣接土粒子の接点数に比例し, また振 動時の運動エネルギによって変化すると仮定すると， 運動摩擦係数は間げき比の関数として表現でき,一般 に間げき比の増加および振動エネルギが増大するとと もに単調に減少するという事実を説明するてとができ る.

(昭和 41 年 5 月 18 日 日本材料学会第 15 期総会講演会にて講演)

参 考 文 献

1) Thurston, C.W., and H. Deresiewicz, J. App. Mech. 26, Trans. ASME, 81, 251 (1959).

\title{
Advanced Optical Techniques（最近の光学技術）
}

\author{
A.G.S. ヴァン ヒール 編
}

(B5 判変形, 678ページ, 12960円，1967年, North-Holland Publishing Co. 発行)

ファイバースコープ，レーザなどが商品となり，ホ ログラフィの記事が雑誌をにぎやかすようになると， 多方面にわたる工学関係者は, 光学をあらためて見直 してみなければならない. 確かに, 光学というものは 古くに完成してしまった学問ではなく, 他の分野と同 様に近年富みに進歩しているてとを本書は浮き彫りに している. こういう書評者自身は, 光学の專門家でな く, 必要に応じて光学機械を使用しているにすぎな 素人であるが, 光学発展の息吹きを身近に感じていた ので，編者と書名に引かれて書物を開いてみたわけで ある。

本書の内容は次の項目に分かれている．執筆者を世 界中に求めているのは編者の見識に真うものであろう.

Precision measurements, Isotropic and anisotropic media, Principles of instrumental methods in spectroscopy, Interferometry, Optics of thin films, The theory of coherence and its applications, Use of spheres in optics, The production of optical parts, Modern light sources, The coronagraph, Fiber optics, A precision interferometer with high lightgathering power, Alignment, Lasers, Optical glass, Geometrical optics, Design of optical instruments, Measurement of aberrations and optical transfer functions of optical systems.

以上の項目で明らかなように，実際上に応用されて いるものをとりあげ，最近の成果およびやや高級な事 項を多方面にわたって選び，それぞれについての要点 を解説して基本的な理論と結びつけ，さらに実際との 橋渡しをしようとするのが編者の意図である。とのよ うな意図は充分に達せられているようであるが，記述 内容は，各項目の性格に応じてかなりの差がある。た とえば，研究成果の要約に近いものもあれば，実用上 の重要事項につき解説を加えて最近の資料を添えるの に力を注いだものもある。

色彩関係の記述はないが，本書一冊で最近の応用光 学方面の大部分は展望できる。書評者のように, 全編 を通読するほどの意志を持っていない者にとっても有 難いのは，巻末に親切な索引がついているのでハンド ブックとして活用できる点である．レーザや各種光源 についての資料を求めることもできるし，拾い読みを していて研究上役だつ事実を知ったり, 光学機械の製 作や検査についての知識を得るととも多いと思われる。 より詳細を学ぶためには, 記載されている文献が非常 に役だつであろう. 物理学者, 工学者, 各種機械の製 作に携わっている者のいずれでも利用できる. (京都大学工学部交通土木 森 忠 次) 